\title{
User's Rights and the Public Domain
}

\author{
Hugh Breakey" \\ Political Philosophy and T. C. Beirne School of Law, University of Queensland, Australia
}

\begin{abstract}
In recent years the concept of "user's rights" has gained considerable currency in discussions of the limits of intellectual property in general, and of copyright in particular. Those arguing in favour of the public domain and increased limitations on copyright have increasingly sought to fight fire with fire - to place substantive user's rights against the claims of intellectual property. User's rights have in some jurisdictions received explicit Supreme Court imprimatur and they are expressly recognised in charters of human rights. Yet there is a residual uncertainty about the appropriateness of this language. Is it correct, as a general conceptual and normative matter, to speak of the broad liberties citizens have regarding access to ideas and information as rights? The few treatments dealing directly with this question have argued - often from a Hohfeldian footing - that ascriptions of user's rights are inappropriate. Even commentators largely sympathetic to the public domain have found themselves drawn to this conclusion. In this article, I vindicate the general applicability of rights language by arguing that these deflationary accounts are mistaken —and are mistaken even in terms of the theories of rights they themselves deploy.
\end{abstract}

\section{Introduction}

Ascriptions of user's rights can be found at work in every corner of intellectual property discourse. In everyday legal discussion it is common to hear references to user's rights to quote, for example, and for these to be distinguished from the copying privileges of librarians. ${ }^{1}$ Affirmations of user's rights date back into the earliest history of copyright; notable political philosophers such as John Locke in England, Lord Kames in Scotland, and Condorcet in France spoke the language of natural rights against demands for stronger literary property rights. ${ }^{2}$ More recently, user's rights have become a recurring motif in the burgeoning public domain literature. If we envisage the public domain as all the ideas - and uses of ideas - broadly available to the general citizenry, ${ }^{3}$ then we find user's entitlements to the public domain consistently categorised as rights. ${ }^{4}$ User's rights also may be found in the conclusions of philosophical arguments from ethical first principles. Wendy Gordon's Lockean account of user's rights was the first in a recent series of such arguments, though explicit ethical defences of individuals' rights to learn and know date at least back to J.S. Mill. ${ }^{5}$ Most significantly perhaps, user's rights are increasingly recognised in law. They have received explicit Supreme Court imprimatur in Canada, ${ }^{6}$ and recent First Amendment

\footnotetext{
${ }^{*}$ Thanks to Julian Lamont, Robert Burrell and Kimberlee Weatherall for valuable comments on an earlier draft.

${ }^{1}$ This is so even in jurisdictions where author's rights are central. L. Guibault, Copyright Limitations and Contracts (2002), p.90.

${ }^{2}$ See R. Deazley, On the Origin of the Right to Copy (2004), pp.2-10, 100, 158, 177; M. Rose, "Nine-Tenths of the Law: The English Copyright Debates and the Rhetoric of the Public Domain" (2003) 66 Law and Contemporary Problems 75, 83; M. d. Condorcet, "Fragments Concerning Freedom of the Press" (2002) 131 Daedalus 57; J. Boswell, The Decision of the Court of Session Upon the Question of Literary Property (1774), pp.18-19.

${ }^{3}$ See P. Samuelson, "Challenges in Mapping the Public Domain" in L. Guibault and P. Hugenholtz (eds), The Future of the Public Domain: Identifying the Commons in Information Law (2006), p.16.

${ }^{4}$ e.g. D. Lange, "Recognizing the Public Domain" (1981) 44 Law and Contemporary Problems 147; Y. Benkler, "Free as the Air to Common Use: First Amendment Constraints on Enclosure of the Public Domain" (1999) 74 N. Y. U. Law Review 354, 367, 428; D. Vaver, "Reforming Intellectual Property Law: An Obvious and Not-So-Obvious Agenda" [2009] I.P.Q. 143, 159-160.

${ }^{5}$ W. Gordon, "A Property Right in Self-Expression: Equality and Individualism in the Natural Law of Intellectual Property" (1992-3) 102 Y.L.J. 1533; J. Waldron, "From Authors to Copiers: Individual Rights and Social Values in Intellectual Property" (1993) 68 Chicago-Kent Law Review 841; H. Mitchell, The Intellectual Commons: Toward an Ecology of Intellectual Property (2005). Re Mill, see below fnn. 19 and 20.

${ }^{6}$ CCH Can. Ltd v Law Society of Upper Canada [2004] S.C.C. 13.
} 
decisions in the United States have a substantial "user's rights" tenor. ${ }^{7}$ Both the European Convention on Human Rights and the Universal Declaration of Human Rights expressly recognise rights not only to speak and impart ideas, but also to seek and receive information. ${ }^{8}$ They recognise, that is, user's rights.

But is there anything more to these ascriptions of rights than rhetorical flourish? Or-worse still—is this yet another example of the all-too-common distension of the core notion of rights? Few of those arguing in favour of user's rights have confronted the general question regarding the applicability of this language. More worrying, those commentators who have directly broached this larger question — particularly Edward Samuels and John Cahir-have concluded the ascription of rights is not justified. ${ }^{9}$ Even commentators, such as Lucie Guibault, ${ }^{10}$ otherwise sympathetic to the importance of the public domain have acknowledged there are significant concerns with the appropriateness of this language.

In each of the following three sections, I argue that the conclusions of Samuels, Cahir and Guibault are mistaken, and that they are mistaken even in terms of the theories of rights they themselves deploy. In so doing I aim to exonerate the general use of the language of user's rights.

Why does this question matter? It matters, briefly, because whether or not there are rights at stake has consequences for the scope, substance and strength of intellectual property rights. In terms of strength, as David Vaver notes, if copyright is to be understood as a reasonable balance between authors and users, then it needs to be a balance of like against like, not of author's rights against the public's privileges. ${ }^{11}$ It matters in terms of scope and substance when we consider, for example, the "exceptions" to copyright. If the concerns of librarians are quite distinct from educators, from journalists, from comedians, and all those are separate from the worries of the rest of us, then it is appropriate to have narrow exceptions catering for the idiosyncratic needs of specific groups. However, if there is a basic right explaining many of these applications, but nevertheless applying for ordinary folks as well, ${ }^{12}$ then narrow exceptions will be less likely to assuage our ethical concerns.

Note that these issues of strength and scope matter irrespective of the ultimate moral ground of user's rights. Rights of individuals to apprehend, search, learn and know might be justified as natural rights — but they may as easily be grounded in purely utilitarian commitments, placing emphasis on the countless human interests and public benefits facilitated by entitling citizens to learning, culture, wisdom and knowledge.

\section{Samuels: the nature of user's rights and the public domain}

In an early critique, Edward Samuels contended the public domain is "not so much a theory as a tendency to resolve borderline or new cases in favor of nonprotection rather than protection". ${ }^{13}$ Samuels" observation - made in 1993 - remains relevant today. ${ }^{14}$ Many public domain advocates have gestured towards the existence of user's rights in the public domain without giving any systematic account of these rights' nature, limitations, ethical justifications or potential applicability outside the realm of intellectual property. As such, their confident ascriptions of rights can have an ad hoc, piecemeal and even "magical" flavour to them. ${ }^{15}$

\footnotetext{
${ }^{7}$ Benkler, "Free as the Air to Common Use" (1999) 74 N. Y. U. Law Review 354, 366; N. Netanel, "Locating Copyright within the First Amendment Skein" (2001) 54 S.L.R. 1; L. Patterson and S. Lindberg, The Nature of Copyright: A Law of Users' Rights (1991), p.124.

${ }^{8}$ European Convention on Human Rights art.10 and Universal Declaration of Human Rights art.19. Similarly art.19(2) of the International Covenant on Civil and Political Rights.

${ }^{9}$ E. Samuels, "The Public Domain in Copyright Law" (1993) 41 Journal of the Copyright Society 137; J. Cahir, "The Public Domain: Right or Liberty?" in C. Waelde and H. L. MacQueen (eds), Intellectual Property: The Many Faces of the Public Domain (2007).

${ }^{10}$ Guibault, Copyright Limitations and Contracts, 2002, pp.90-98.

${ }^{11}$ Vaver, "Reforming Intellectual Property Law" [2009] I.P.Q. 143, 160

${ }^{12}$ Waldron, "From Authors to Copiers" (1993) 68 Chicago-Kent Law Review 841, 861-862.

${ }^{13}$ Samuels, "The Public Domain in Copyright Law" (1993) 41 Journal of the Copyright Society 137, 138; qv 143.

${ }^{14}$ Note the similar observation by J. Boyle, "The Second Enclosure Movement and the Construction of the Public Domain" (2003) 66 Law and Contemporary Problems 33, 67.

${ }^{15}$ Samuels, "The Public Domain in Copyright Law" (1993) 41 Journal of the Copyright Society 137, 150.
} 
But it is not impossible to get an idea of what most public domain theorists seem to have in mind. There are, I think, four ways of characterising the types of general user's rights found in the literature. I separate them here for conceptual clarity, but naturally there is no impediment to holding that all four types of user's rights are required.

First, user's rights may be seen as one part of the right to free speech. ${ }^{16}$ Intellectual property allocates, as Neil Netanel puts it, "speech entitlements". ${ }^{17}$ Restrictions on copying expressions and ideas-especially insofar as such copying is used for creating derivative works, for research, and for critical review-are manifestly restrictions on speech. So user's rights might be that subset of free speech rights applying to the expression and reworking of others' ideas, discoveries and expressions.

Secondly, user's rights may be understood as rights to be provided with an ideational milieu of a certain quality and quantity - perhaps incorporating properties of applicability, richness and diversity. ${ }^{18}$ On this view, the state has responsibilities to ensure diverse voices can be heard, and perhaps even to ensure there are incentives to create new ideas, expressions and discoveries. The idea that copyright is itself an "engine of free expression", inasmuch as it fuels new creations and possibilities, is one reflection of the thought that free expression includes some concern for the quality and applicability of the informational environment available to citizens.

Thirdly — and closely related — is the right to informed action. ${ }^{19}$ On this approach, citizens have a right to have information and ideas actively disseminated to them, and to have the capacity to act on such. Somewhat similar to a positive right to education, or to a welfarist right to fair distribution of some primary good, individuals have a right to those intellectual resources required for them to live their lives wisely, autonomously and responsibly. The state is in this case not merely providing a quality resource for people to engage with as their skill and motivation allow-its role is to actually get the relevant information into the minds of those who need it.

Fourthly, we have what might be termed the right to intellectual liberty - the right of people to live better, freer and more self-directed lives by being able to inform their actions by learning for themselves. ${ }^{20}$ This is a classical liberal right-both in the sense that it is constituted by negative duties of non-interference, ${ }^{21}$ and in that we can find substantial evidence of its presence in the classical liberal canon. ${ }^{22}$ It is a freedom from the ways others can stop us learning about the world or putting into action what we have learned.

Naturally, distilling these four possibilities is a considerable distance from offering a substantive theory delineating and justifying them. However, these examples should be sufficient to serve our purposes in the following argument — and they illustrate there is something more than a "tendency" at work here.

\footnotetext{
${ }^{16}$ L. Lessig, "The Creative Commons" (2004) 1 Montana L.R. 1, 10; Gordon, “A Property Right in Self-Expression” (1992-3) 102 Y.L.J. 1533, 1558, 1570, 1588-1594; Benkler, "Free as the Air to Common Use" (1999) 74 N. Y. U. Law Review 354, 358, 427-433.

${ }^{17}$ Netanel, "Locating Copyright within the First Amendment Skein" (2001) 54 S.L.R. 1, 55.

${ }^{18}$ Mitchell, The Intellectual Commons, 2005, pp.22, 97, 106-107, 165; Patterson and Lindberg, The Nature of Copyright, 1991, pp.50-3; J. Mill, On Liberty (E. Rapaport (ed.), 2003) p.54; Gordon, "A Property Right in Self-Expression" (1992-3) 102 Y.L.J. 1533, 1555-1559; Benkler, "Free as the Air to Common Use" (1999) 74 N. Y. U. Law Review 354, 365-367, 381-384.

${ }^{19}$ Benkler, "Free as the Air to Common Use" (1999) 74 N. Y. U. Law Review 354, 382-383; Patterson and Lindberg, The Nature of Copyright, 1991, pp.124-126, 128, 209, 240; J. Mill, Utilitarianism 2nd edn (2001), p.14; T. Campbell, "Rationales for Freedom of Communication" in T. Campbell and W. Sadurski (eds), Freedom of Communication (1994), pp.32-33. The stronger interpretation of the articles regarding the receipt of information and ideas in charters of human rights (see text to fn.9 above) affirms this right to information. On a weaker construal they propose only negative rights to learn for oneself: see text to fn. 21 below.

${ }^{20}$ There are at least suggestions of this possibility in: Benkler, "Free as the Air to Common Use" (1999) 74 N. Y. U. Law Review 354, pp.358, 382-383, 390; Gordon, “A Property Right in Self-Expression" (1992-3) 102 Y.L.J. 1533, 1563-1564.

${ }^{21}$ I. Berlin, Four Essays on Liberty (1969), pp.121-127.

${ }^{22}$ See references to Locke, Kames, and Condorcet in fn.3 above; Mill, On Liberty, 2003, pp.55-56, 65, 104-105. This commitment to the freedom to learn for oneself suffuses the entire liberal tradition of education - from Locke, through Rousseau, to Dewey - and it arguably gives the Enlightenment its very name: I. Kant, “What is Enlightenment?" in P. Gay (ed.), The Enlightenment: A Comprehensive Anthology (1973), pp.384-388.
} 
Samuels's second concern is that it is altogether unlikely the public domain is some internally delineated realm constituting the full set of uses-of-ideas ordinary persons are at liberty to make. ${ }^{23} \mathrm{He}$ draws a telling analogy to Hofstadter's musing upon the set of prime numbers. ${ }^{24}$ While all prime numbers share a quality, Hofstadter ruminates, they do not share a form - they are just the set of numbers left over when all the non-primes have been removed. So too, Samuels suggests, for the set of freedoms over ideas; it is just the set left over after intellectual property and other entitlements have been given their due, as balanced with whatever other political concerns are relevant. ${ }^{25}$ Pressing his point home, Samuel marshals another, closely related charge: it is implausible that any one moral right (perhaps even any one moral paradigm) can possibly explain all of the involute intricacies of contemporary copyright regimes. ${ }^{26}$

The best response to Samuel's initial point regarding the prospects for internal delimitation of the public domain is, I think, to hold that the idea of user's rights is primary and fundamental, and the notion of the public domain is secondary and derivative. The nature and boundaries of the public domain are where our normative analysis should finish, not where it should begin. As Samuels observes, it is hardly as if all the ideas in the public domain share some particular quality that has them earmarked for required dissemination. But acknowledging this does not prevent us accepting user's rights. After all, we do not reject the right to free speech simply because we cannot find an independent quality subsisting in all and only the propositions whose utterance is protected by that right. ${ }^{27}$ We would never expect to find any such quality. In the cases of both free speech and user's rights we begin with the importance to individuals of a particular interest or freedom - the freedoms to speak, learn or know, for example - and we finish with the host of entitlements in law protecting and facilitating that freedom.

The same response may be put to Samuels's argument that no one single right can explain and justify the contours of the public domain. It is the same with all rights. The right to free speech is a pressure, deployed in any given case against other moral pressures, and shaped in the light of myriad prosaic factors such as practicality, predictability and enforceability. Similarly for user's rights. And similarly, of course, for intellectual property itself. The public domain is as muddled and interpenetrated as the property regime that forms its silhouette.

Samuels presents one final worry: ascriptions of rights to the public domain threaten to treat "the problem with an all or nothing approach". ${ }^{28}$ There is an irony here. For decades public domain theorists have-some notable exceptions aside-levelled exactly the same charge at theories of intellectual property rights. Such theories, they claimed, have no space for nuance and balance - there is only the peremptory black-and-white of property rights. Now Samuels threatens to hoist public domain theorists on their own petard; claims of rights are unhelpful on subtle questions of intellectual property, they are told, because they are too decisive a moral force.

It is certainly true that accepting some entitlement as property or as a right makes a substantial difference to its scope and strength in law and political theory. ${ }^{29}$ But it is an error to think, as Samuels does, that such a status necessarily makes the entitlement all or nothing. All rights - even the most basic human rights - have substantial limitations arising both from internal theoretical constraints (e.g. universalisability) and from external pressures (e.g. the scope of others' rights). It is fully consistent to assert individuals have rights to free speech while accepting these freedoms will be limited by others' rights not to be slandered. Analogously, it is entirely coherent to assert individuals have user's rights without requiring such entitlements be decisive in all issues against all competing considerations.

\footnotetext{
${ }^{23}$ Samuels, "The Public Domain in Copyright Law" (1993) 41 Journal of the Copyright Society 137, 137-138, 149, 180-181.

${ }^{24}$ Samuels, "The Public Domain in Copyright Law" (1993) 41 Journal of the Copyright Society 137, 137.

${ }^{25}$ Samuels, "The Public Domain in Copyright Law" (1993) 41 Journal of the Copyright Society 137, 137-138.

${ }^{26}$ Samuels, "The Public Domain in Copyright Law" (1993) 41 Journal of the Copyright Society 137, 149, 180-181; qv. Boyle, "The Second Enclosure Movement and the Construction of the Public Domain" (2003) 66 Law and Contemporary Problems 33, 52.

${ }^{27}$ T. Scanlon, "A Theory of Freedom of Expression" (1972) 1 Philosophy and Public Affairs 204, 208.

${ }^{28}$ Samuels, "The Public Domain in Copyright Law" (1993) 41 Journal of the Copyright Society 137, 176-177.

${ }^{29}$ See the analysis of rights in T. Campbell, The Left and Rights (1983), p.93.
} 


\section{Cahir: the Hohfeldian analysis}

John Cahir mounts a multi-faceted argument against public domain theorists" cavalier use of the "R"-word. ${ }^{30}$ To assess Cahir's argument we need to sharpen the meaning of that notoriously slippery term "right". Allow me to stipulate a substantive right as being some individual's interest, activity or choice (or, as Cahir puts it, a concern $^{31}$ ) being intentionally protected or facilitated by various legal measures. Cahir argues against the existence of any substantive user's rights - especially any such right as may undermine the enclosure of information through the use of digital rights management (DRM) devices. ${ }^{32}$

Cahir puts forward four arguments against rights to the public domain. His first argument draws heavily on the Hohfeldian analysis of the right. My critiques of his argument are made in these terms, so it is necessary for us to briefly cover Hohfeld's classic treatment. ${ }^{33}$ One caveat however: for reasons that will shortly become clear, I have altered Hohfeld's terminology. ${ }^{34}$

For our purposes, there are four jural-relations worth discussing. First, if Alf has a liberty to $\varphi$ then he has no duty not to $\varphi$ - he is at liberty to $\varphi$ because he is not legally bound to avoid engaging in $\varphi$ 'ing. Secondly, if Alf has a claim against Betty regarding $\varphi$ then she has some duty to Alf regarding $\varphi$ - the paradigm case occurs when Betty has promised to give Alf $\varphi$; as Betty is duty-bound to Alf to give him $\varphi$, so Alf has a correlative claim against Betty that she do so. A power is the capacity to alter the legal-relations of some person. For instance, in the foregoing example Betty used her power to promise in order to alter Alf's claims by imposing new duties on herself (namely to give Alf $\varphi$ ). Waiving, promising, abandoning and alienating are archetypal powers. Finally, to have an immunity regarding $\varphi$ is for it to be the case that no person has the power to alter one's legal-relations regarding $\varphi$. For instance, if Betty owns $\varphi$ then she typically has an immunity against Alf such that Alf cannot unilaterally dissolve her claims over $\varphi$.

Cahir draws on Hohfeld's terminology in contending that rights (strictly connoted) are exclusively claims. As a terminological matter this is quite correct-I must confess in the above description I used the term "claim" where Hohfeld used the term "right". My reason for doing so is expository; it grants us the linguistic resources to assess, as we will shortly do, Hohfeld's stipulation that "rights" are "claims". Relying on this equation of rights with claims, Cahir says:

"If one asserts that individuals have some right to the public domain, the logical corollary is that some other individual or entity is under a positive duty to do some act or refrain from doing some act with respect to the interest that is protected by that right." ${ }^{935}$

Cahir then argues that putative legal rights in the public domain — rights of access in particular-are not claims. However access entitlements are constituted in law, it is not, he thinks, as claims. Ex hypothesi then, he concludes, access entitlements are not rights. Cahir is not alone on this point. Lucie Guibault was earlier drawn to this conclusion by a similar Hohfeldian analysis. ${ }^{36}$

Accepting momentarily the premise that rights must be claims, it is not clear why Cahir thinks user's entitlements can't include claims. After all, many accounts of user's entitlements involve the imposition of duties. Lindberg and Patterson argue the entire copyright edifice, in the United States at least, was built

\footnotetext{
${ }^{30}$ Cahir, "Right or Liberty?" in Intellectual Property: The Many Faces of the Public Domain, 2007, p.38.

${ }^{31}$ Cahir, "Right or Liberty?" in Intellectual Property: The Many Faces of the Public Domain, 2007, p.38.

${ }^{32}$ The nature of Cahir's arguments and their conclusions require he is speaking of substantive rights: see Cahir, "Right or Liberty?" in Intellectual Property: The Many Faces of the Public Domain, 2007, pp.35, 36, 38, 46, 52; similarly, J. Cahir, "The Moral Preference for DRM Ordered Markets" in F. Macmillan (ed.), New Directions in Copyright Law (2005), pp.48, 51.

${ }^{33}$ W. Hohfeld, Fundamental Legal Conceptions, as Applied in Judicial Reasoning (1946). For a lucid adaptation to moral rights: L. Wenar, "The Nature of Rights" (2005) 33 Philosophy and Public Affairs 223.

${ }^{34}$ I replace Hohfeld's "right" with "claim". I also replace "privilege" with "liberty" (Hohfeld, Fundamental Legal Conceptions, 1946, pp.42-45

flags this possibility.) The former term has a tenor of "exception" that is unapt in the following applications.

${ }_{35}$ Cahir, "Right or Liberty?" in Intellectual Property: The Many Faces of the Public Domain, 2007, p.39; qv pp.36, 41.

${ }^{36}$ Guibault, Copyright Limitations and Contracts, 2002, pp.94-95.
} 
upon their "learning right" - the entitlement of citizens to an accessible and thriving intellectual culture. ${ }^{37}$ Yochai Benkler contends the First Amendment secures US citizens' entitlements to a public realm where diverse voices can be heard. ${ }^{38}$ The protecting of these sorts of entitlements requires the imposition of restrictive duties upon myriad persons. ${ }^{39}$ Furthermore, it is at least arguable that the duties others have not to interfere with our reciting Shakespeare (say) necessarily must be-because of the basic Hohfeldian correlativity thesis - correlatives of our claims to perform such recitals. That is, these duties of non-interference can only be correlatives of user's rights. ${ }^{40}$ To be sure, all three of these accounts of user's rights are controversial. My point is simply to note that if any such lines of argument were to be substantiated, users must be adjudged to hold rights even under the narrow terms of Cahir's argument.

But be this as it may, the central problem with Cahir's argument is its dependence on his insistence that only claims are rights. Since Hohfeld also stipulates thus, it is worth noting that for Hohfeld nothing substantive rested on this terminological choice. Hohfeld simply needed some word to refer to the correlative of a duty. Though he was well aware of the broad connotations of the term "right", Hohfeld found legal-historical warrant for a narrower usage — wherein one person's "right" correlated tightly with another person's duty. ${ }^{41}$ (Noting the term's broader meaning, Hohfeld suggested "claim" might prove a better choice, perhaps excusing my earlier revisionary terminology.) When Hohfeld used the word "right" in his analysis he was talking of it in this narrow stipulative sense. He was making a terminological decision, not decreeing the controversial proposition that all concerns protected by law are only substantive rights if the legal protection of that concern is effected by claims. But that proposition is what Cahir's argument requires. ${ }^{42}$ When Cahir tells us that all rights are claims he is doing much more than following Hohfeld's terminological stipulation. He is making a bold assertion about the nature of substantive rights.

The reason it is a bold assertion is that all major contemporary theories of rights reject it. Since showing this requires perusing these theories of rights, I will take the opportunity to illustrate-in a more positive mien - how user's rights prima facie fit within the criteria set down by each theory.

"Will" or "choice" theories of rights assert that, strictly speaking, only Hohfeldian powers are rights. ${ }^{43}$ The claims a baby has to various others' duties of non-harm, for instance, are not rights because they cannot be waived or alienated (and hence the baby has no powers over them; hence, concludes the Will theorist, they are not rights). For the Will theorist therefore, contrary to Cahir's assertion, rights are not claims. Whether or not user's entitlements are Will theory rights depends pivotally on whether users can waive, trigger or transfer those entitlements. While we cannot know for certain the answers to these questions except by investigating each theory of user's rights in turn, there seems no reason to suppose user's entitlements could not at least be waived. Just as individuals can promise or contract away their liberties to speak, it seems likely they will be able to behave similarly regarding their liberties to seek out or receive ideas. If so, then they have rights sensu Will theory.

\footnotetext{
${ }^{37}$ Patterson and Lindberg, The Nature of Copyright, 1991, pp.50-53.

${ }^{38}$ Benkler, "Free as the Air to Common Use" (1999) 74 N. Y. U. Law Review 354, 365-367, 381-384.

${ }^{39}$ Lindberg and Patterson's "learning right" imposes duties on citizens to shoulder the load required for the growth of culture by paying copyright's dues, while Benkler's commitment to a diverse and decentralised informational milieu requires restricting the freedoms of, for example, cable providers.

${ }^{40}$ There is an error in Cahir's rendering of Hohfeld requiring mention here. Cahir, "Right or Liberty?" in Intellectual Property: The Many Faces of the Public Domain, 2007, p.37) defines a "privilege (liberty) to $\varphi$ “" as others having "no right" to interfere with my $\varphi$ 'ing. This is incorrect. If I have the privilege to $\varphi$ then what others have is no (claim-)right that I refrain from $\varphi$ 'ing. As Hohfeld is at pains to emphasise, it is consistent with my having a privilege (liberty) to $\varphi$ that others are able to interfere with my $\varphi$ 'ing: Hohfeld, Fundamental Legal Conceptions, 1946, pp.39-42 (qv p.49 where Hohfeld selects the term "privilege" over "liberty", in part precisely to avoid the latter's connotation of non-interference). This error becomes significant when Cahir discusses the freedom we have to stage Shakespeare productions ("Right or Liberty?", 2007, p.40). We are at liberty to do so because Shakespeare's descendants have no claim against us that we do not-we have no duty to forebear. But do we also have claims of non-interference such that others are duty-bound not to interfere with our doing so? Cahir's imprecise exposition of Hohfeld's "liberty" makes it easier for him to avoid asking this important question because he has (erroneously) linked non-interference to liberties, rather than (correctly) to claims.

${ }^{41}$ Hohfeld, Fundamental Legal Conceptions, 1946, pp.38, 71.

42 The nature of Cahir's argument and conclusions require he is speaking of a substantive right. See above fn. 33 .

${ }^{43}$ See: Wenar, "The Nature of Rights" (2005) 33 Philosophy and Public Affairs 223, 238-239; H. Steiner, "Working Rights" in M. Kramer, N. Simmonds and H. Steiner (eds), A Debate over Rights (1998), p.247; H. Hart, Essays on Bentham (1982), pp.183-188; H. Hart, "Are There Any Natural Rights?" (1955) 64 Philosophical Review 175, 178, 181.
} 
"Interest" theories of rights are more expansive. Joseph Raz initially defines rights as interests of an individual constituting a sufficient reason "for holding some other person(s) to be under a duty". ${ }^{44}$ Focused exclusively on the imposition of duties on others, this definition appears in agreement with Cahir's requirement. But Raz clarifies that people's rights may be the ground not only of duties, but also of various entitlements restricting duties or empowering their imposition. In this way he describes how, "rights can be shown to be grounds of immunities and liberties: they are reasons for not subjecting individuals to duties or the power of others". ${ }^{45}$ So, for Raz and interest theories, it turns out that substantive rights can ground powers, immunities and liberties. As I describe below, it is likely that user's entitlements will have (at least) a liberty-immunity structure. If so, and if these entitlements are grounded in order to facilitate some interest of an individual, such as their interest in learning or choosing wisely, then the Interest theory will recognise these entitlements as rights.

Finally, some recent theories of rights are explicitly inclusive: labelling themselves "capacious" theories, they are willing to countenance all manner of Hohfeldian jural-relations - including claims, powers, liberties and immunities — as being rights. ${ }^{46}$ Capacious theories bring in additional criteria for discerning which of these jural-relations (or clusters of relations) counts as a right in any given instance. For example, Leif Wenar requires that the entitlements serve particular functions, such as protection against harm, provision for those in need, or discretion of choice. ${ }^{47}$ Clearly, the user's rights sketched earlier can fulfil functions of provision (of information to those who need it) and discretion (regarding what and whether to learn). In all, each of the major contemporary theories of rights decisively and explicitly denies Cahir's premise that all rights are claims, and, a fortiori, each advances criteria that user's rights prima facie fulfil.

Nor is it merely in terms of modern theories of rights that Cahir's position is flawed. His account pays no heed to the substantive-rights status intuitively accorded to various liberties, powers and immunities. The latter omission is particularly puzzling since Cahir himself observes that a "constitutionally protected right of free expression will normally entail that individuals have an immunity ...". Cahir's categorisation of this immunity (more fully, this liberty-immunity conjunct) as a right is little more than the acknowledgment of a commonly accepted legal-philosophical truism. ${ }^{49}$ Yet if liberty-immunity conjuncts are rights then rights plainly must be more than only claims. ${ }^{50}$

In all, both theory and practice decisively contradict Cahir's lynchpin premise that rights must be exclusively claims. Rejection of this premise opens a space for other Hohfeldian structures - such as the liberty-immunity conjuncts of free speech - to be recognised as substantive rights.

As it happens, this particular right-structure - the liberty-immunity conjunct - is relevant to our inquiry. The most plausible construal of each of the four renderings of user's rights sketched earlier will include (at least) this structure. The liberty consists in liberties to copy, access, use, or search out ideas and information. The immunity prohibits the liberty's dissolution by certain types of duty-impositions, such as might be imposed by intellectual property, or by the outlawing of technology that could circumvent digital enclosure. If courts and legislatures refrain from imposing such duties out of respect for individual's interests in and choices over using and learning ideas, then there would be no impediment to referring to these liberty-immunity conjuncts as rights.

\footnotetext{
${ }^{44}$ J. Raz, The Morality of Freedom (1986), p.166.

${ }^{45} \mathrm{Raz}$, The Morality of Freedom, 1986,p.168.

${ }^{46}$ R. Cruft, "Why Aren't Duties Rights?" (2006) 56 The Philosophical Quarterly 175, 178; Wenar "The Nature of Rights" (2005) 33 Philosophy and Public Affairs 223, 236.

${ }^{47}$ Wenar, "The Nature of Rights" (2005) 33 Philosophy and Public Affairs 223, 246.

${ }^{48}$ Cahir, "Right or Liberty?" in Intellectual Property: The Many Faces of the Public Domain, 2007, p.37.

${ }^{49}$ Wenar, "The Nature of Rights" (2005) 33 Philosophy and Public Affairs 223, 232, 235.

${ }^{50}$ This very example (free speech as a liberty-immunity conjunct) was used to refute the duty-right correlativity thesis in D. Lyons, "The Correlativity of Rights and Duties" (1970) 4 Nous 45, 52.
} 
Cahir's second argument asserts that upholding "a free-standing general right" to gain access to information would mean individuals (he suggests diarists and temperamental poets) would be under "a duty to make that information available to other persons on demand". ${ }^{51}$ The problem here is this ambiguous phrase "free-standing general right". On the one hand, if Cahir means that the right is plenary - that is, it is a right to absolutely all information and it trumps absolutely all other considerations - then his argument is valid, but vacuous. His reductio ad absurdum only works on arguments either explicitly drawing such plenary conclusions, or having premises leading to them. Neither quality can be attributed to any major public domain theories.

On the other hand, if by "free-standing general right" Cahir means only that certain types of access to certain types of information are an ongoing general right of ordinary individuals, then the stated conclusion simply doesn't follow. Consider an analogy: suppose someone (e.g. Locke ${ }^{52}$ ) asserted that individuals have a natural right to labour in the world, including a right of access to resources. It would be idle to claim this right is absurd ${ }^{53}$ on the basis of the obvious fact that people do not have a natural right to access, much less the right to make things out of, my body-parts. Locke is not claiming a right to labour on everything and he is not claiming this consideration trumps all others. Nor do his underpinning arguments carry any such consequence. The analogous point follows regarding rights to access information and ideas; there is no reason to assume such rights are plenary.

Cahir's third argument allows there may be "non-individuated socio-economic interests" such as the "general public interest in gaining access to education and cultural information" at stake in these questions. ${ }^{54}$ But he urges such interests should not be facilitated by altering the prior rights of individuals. Cahir begins by noting the substantial differences between various theories of rights - such as between Robert Nozick's libertarian negative rights and other more welfarist positive rights. ${ }^{55}$ Notwithstanding these theories' various other disagreements, Cahir asserts it is nevertheless:

"... generally agreed that if non-individuated socio-economic interests are to be recognized as grounding individual rights they can, at most, impose duties on the state; they do not legitimate, either under negative or positive rights theory, the imposition of duties directly on private actors." 56

This is just false. ${ }^{57}$ Worse, it is false even in terms of Cahir's own examples. Consider, for instance, Nozick's access rights. Nozick holds that resources like water-holes can be appropriated by individuals. ${ }^{58}$ But if and when other surrounding water-holes dry up and others no longer have the access to resources they previous enjoyed, Nozick requires the property rights over the remaining water hole dissolve. This change in property rights forced by others' access rights involves the direct imposition of new duties on specific individuals. The prior owner now acquires new (negative) duties not to interfere with others helping themselves to the resource - duties she did not have when she was an owner. Contrary to Cahir's claim then, there is nothing surprising in theories of rights having rights of access directly imposing particular duties on, or removing particular claim-rights from, specific persons. ${ }^{59}$ Indeed, it would be a

\footnotetext{
${ }^{51}$ Cahir, "Right or Liberty?" in Intellectual Property: The Many Faces of the Public Domain, 2007, pp.46-47; qv Cahir, "Moral Preference for DRM" in New Directions in Copyright Law, 2005, p.51. One further problem is the structurally ambiguous nature of the duty Cahir draws out. Does he mean a negative duty to allow others access, or a positive duty to actually hand the information over to others?

52 J. Locke, Two Treatises of Government (1947), Bk II, §33, §36.

${ }^{53}$ Or even that it had a "heavy burden" of proof: Cahir, "Right or Liberty?" in Intellectual Property: The Many Faces of the Public Domain, 2007, p. 47.

${ }^{54}$ Cahir, "Right or Liberty?" in Intellectual Property: The Many Faces of the Public Domain, 2007, p. 47.

${ }^{55}$ Cahir, "Right or Liberty?" in Intellectual Property: The Many Faces of the Public Domain, 2007, p.47.

${ }^{56}$ Cahir, "Right or Liberty?" in Intellectual Property: The Many Faces of the Public Domain, 2007, p.48.

${ }^{57}$ I presume Cahir's "non-individuated socio-economic interests" include interests members of the general public may have in accessing resources where such access requires the direct imposition of new duties on specific other individuals or the direct (redistributive) dissolution of these others' property-rights. Any narrower construal of the scope of Cahir's referent would fail to establish his conclusions: see above fn. 33 .

${ }_{58}^{58}$. Nozick, Anarchy, State, and Utopia (1974), pp.179-180.

${ }^{59}$ Intriguingly, it is even possible Nozick provides a counter-example to Cahir on the exact issue under discussion —rights of access to information: Nozick, Anarchy, State, and Utopia, 1974, p.330.
} 
surprise if it were otherwise - given that we can find judicial recognition of these sorts of rights of direct access in actual legal practice. The shopping mall and gated residential community cases, for example, are a paradigm of the court's willingness and capacity to delineate public rights of access - even on the basis of the common law itself - into privately held resources. ${ }^{60}$ And even justiciable rights of informational access are not foreign to the courts - as the cases surrounding Red Lion Broadcasting Co v FCC attest. ${ }^{61}$

But perhaps (it might be speculated) Cahir is gesturing towards a slightly different argument. Perhaps his focus is not so much on the capacity of individual's rights of access to impose new duties on particular persons, but rather on the capacity of collective rights to do so. Suppose Alf is under a duty created by the state for reason of Betty's and everyone else's legitimate interest in having knowledge. Because of the collective nature of the reason for imposing the duty it may seem unapt to say Alf owes the duty toBetty - Cahir may be reasoning that Betty has a right only when some individual (Alf) has a duty to her. There are some cases where the citizenry's legitimate interests and their manner of protection are sufficiently collective in nature that this line of argument is plausible. Environmental law perhaps provides an example; it is at least arguable Alf's duties not to pollute are not duties toBetty, even if Betty is a suffering asthmatic. But in the matter of user's rights to access information the relationship between Betty's interest and Alf's breached duty is much tighter. When Alf fails in his legal duty to ensure Betty can make fair use of his works, Betty's legitimate interest in using Alf's works is set back. The tightness of relation between Betty's interest and Alf's breached duty in such a case suggest no principled reason for resisting saying Alf breached his duty toBetty — and thus violated her rights.

Fourthly and finally, Cahir argues it is an error to look exclusively to copyright law in order to delineate legal norms regarding information policy. ${ }^{62}$ Doubtless this call for breadth of vision is salutary. But where else to look? Rights of free speech and freedom of the press clearly shape our information policy, and so too may the rights to seek and receive information and ideas expressly recognised in contemporary charters of human rights. ${ }^{63}$ But Cahir advances another possibility - perhaps we should look to the law of private (i.e. tangible) property. Cahir thinks the law of private property supports the use of digital rights management (DRM) devices to enclose information and prohibits the use of technology circumventing such DRM enclosure..$^{4}$

Using the law of private property to fashion informational policy is an intriguing suggestion, and I will here pursue it sufficiently to refute - or at least seriously weaken-Cahir's claim that property rights prohibit circumvention technology. But when the argument is completed the reader may perhaps join me in thinking that private property in law is not the most attractive scaffold from which to construct our information policy. Indeed, they may be inclined to think the most attractive information-policy feature of property law is not internal to it at all, but rather resides in the many ways property in law defers to external informational rights like free speech. ${ }^{65}$

In any case, to make his argument Cahir analogises to a homeowner padlocking his front door-something the homeowner is unquestionably entitled to do. ${ }^{66}$ But is this analogous to Alf sending coded transmissions through his neighbour's (Betty) property and requiring she refrain from using her radio-receiver and code-breaking equipment? Or analogous to a case where Alf sells Betty a chattel and subsequently demands she not use her software to bypass various limitations on the chattel's use Alf tried

\footnotetext{
${ }^{60}$ K. Gray and S. Gray, "Private Property and Public Property" in J. McLean (ed.), Property and the Constitution (1999), pp.20-35. The authors explicitly note the potential analogy to informational domains: see p. 30 .

${ }^{61}$ See Benkler, "Free as the Air to Common Use" (1999) 74 N. Y. U. Law Review 354, 367-377.

${ }^{62}$ Cahir, "Right or Liberty?" in Intellectual Property: The Many Faces of the Public Domain, 2007, p.49.

${ }^{63}$ E. Samuels, "The Public Domain in Copyright Law" (1993) 41 Journal of the Copyright Society 137; J. Cahir, "The Public Domain: Right or Liberty?" in C. Waelde and H. L. MacQueen (eds), Intellectual Property: The Many Faces of the Public Domain (2007).

${ }^{64}$ Cahir, "Moral Preference for DRM" in New Directions in Copyright Law, 2005, pp.46-47; Cahir, "Right or Liberty?" in Intellectual Property: The Many Faces of the Public Domain, 2007, p.42-43.

${ }^{65}$ K. Gray, "Property in Thin Air" (1991) 50 Cambridge L. J. 252, 280-291; Gray and Gray, "Private Property and Public Property" in Property and the Constitution (1999), pp.19-30.

${ }^{66}$ Gray and Gray, "Private Property and Public Property" in Property and the Constitution (1999), p.43.
} 
to technologically secure? The answer is at best unclear. Placing a padlock on one's doors prevents others from doing something the law of private property already expressly prohibits - physical trespass. Does the law of private property explicitly (or even just generally) prohibit others from gleaning knowledge from the information flowing across property borders? Does it place non-owners under a duty to exclude themselves from such information - at least in those cases where the owner clearly does not wish for non-owners to apprehend? It does not. As far back as the 18th century Lord Camden decreed that, "the eye cannot by the laws of England be guilty of a trespass" ${ }^{67}$ This view was reaffirmed in the landmark 20th-century case of Victoria Park Racing and Recreation Grounds Co Ltd v Taylor ${ }^{68}$ There the Supreme Court of Australia acknowledged an owner may use such physical means as he can muster, combined with the property-duties proscribing non-owners' physical trespass, to keep secret what he may. But- the majority famously held - if this combination of legal protection and physical enclosure does not suffice to prevent non-owners intentionally accessing the information, then the law of private property affords him no further recourse.

Nor can this decision easily be explained away as a quirk of legal happenstance. Theorists have used this exact issue to gain insight into what they see as the very essence of property in law-namely, that property rights are constituted by duties of non-owners to exclude themselves from the owned res. ${ }^{69}$ In building their cases for this thesis, James Penner and Kevin Gray each note that common law courts, confronted by claims of property in information, do not ask whether the owner has the right to exclude others from the information by building walls or entering contractual arrangements. ${ }^{70}$ That is, courts do not take as relevant the type of consideration Cahir adduces - whether owners can legitimately use DRM devices. Instead, the courts ask whether non-owners have a duty not to apprehend, record, or communicate the information.

If we recall the preceding Hohfeldian analysis, it is evident why this latter question must be the decisive one. The mere fact that property owners are at liberty to encode information cannot settle whether non-owners are under duties not to decode information. We cannot conclude a claim-right from the existence of a liberty. We must confront the question about duties directly. But when we turn our attention to this question, we find property law's answer is the opposite of what Cahir's argument requires: non-owners are under no duty to exclude themselves from information arising from or out of another's property. $^{71}$

Ultimately, the information-enclosures Cahir envisages would be better supported by reference to trade secret law and rights to privacy. I would not wish to discount these latter's capacity to contribute to our information policy - a public domain leaving no space for privacy and even secrecy is as unsettling a world as one where all information is enclosed in politically protected copyright or in politically protected DRM technology. But inasmuch as the law of private property informs our information policy, it guides us toward a middle ground between these extremes. For this reason, Cahir's fourth argument, as with his first three, fails to establish a case against user's rights.

\footnotetext{
${ }^{67}$ Gray, "Property in Thin Air" (1991) 50 Cambridge L. J. 252, 260.

${ }^{68}$ Victoria Park Racing and Recreation Grounds Co Ltd v Taylor (1937) 58 C.L.R. 479. See Gray, "Property in Thin Air" (1991) 50 Cambridge L. J. 252, 264-270.

${ }^{69}$ Gray, "Property in Thin Air" (1991) 50 Cambridge L. J. 252, 259-270; J. Penner, The Idea of Property in Law (1997), pp.71-74.

${ }^{70}$ Gray, "Property in Thin Air" (1991) 50 Cambridge L. J. 252, 279. Penner, The Idea of Property in Law, 1997, pp.73-74. Cahir does not discuss Penner's explicit treatment of this point, despite drawing substantially on his theory: Cahir, "Moral Preference for DRM" in New Directions in Copyright Law, 2005, pp.39-40.

${ }^{71}$ Note one important qualification: there is a set of property cases allowing for property in intangibles like information to arise from one's labour on one's own physical property. See D. Libling “The Concept of Property: Property in Intangibles" (1978) 94 Law Quarterly Review 103. Note however, that (1) it is labour here that is creating these rights, not tangible property itself, and (2) these rights are property rights in intangibles, rather than in physical objects. Not only does Cahir distinguish strongly between these sorts of labour-based rights to intangibles and standard private property in tangibles, he goes to considerable length to reject the legitimacy of the former: Cahir, "Moral Preference for DRM" in New Directions in Copyright Law, 2005, pp.37-45.
} 


\section{Guibault: subjective and objective rights}

Lucie Guibault, drawing on continental European legal concepts, considers whether user's entitlements should be considered subjective or (merely) objective rights. She ultimately consigns user's rights to the latter, weaker category. Guibault's is not a deflationary view in the manner of Cahir; she is keen to emphasise that "legitimate interests" of private users should play a role in the formation of copyright law. ${ }^{72}$ Nevertheless, her argument carries the implication user's entitlements are weaker than intellectual property rights, and it warrants response.

The essence of a subjective right, Guibault explains, requires an intimate relationship between the subject and the object of the right, and the capacity of the subject to control the object of the right. ${ }^{73}$ This subjective right is respected by the general public through their having an enforceable legal duty not to violate this relationship of intimacy and control. The paradigm of a subjective right is thus a property right. ${ }^{74}$ An objective right, in contradistinction, can be created by no more than the reflex effect of the law. If the law regulates certain opening hours for national museums, or grants licences to operate dance halls, then it creates objective rights for those citizens subsequently empowered to visit museums and operate dance halls. ${ }^{75}$

Stated thus it seems user's rights cannot be subjective rights. Following an earlier treatment by Hirsch Ballin, Guibault observes users do not have the required intimacy and control over the works they seek to access and use. ${ }^{76}$ Accepting this judgment momentarily, should this outcome make us think user's rights are merely, as Guibault concludes, objective rights? There are difficulties. For how are we to characterise such human rights as the right to free association? It isn't the case that free association only allows Alf to engage with persons he has a prior intimate relationship with, and nor does it empower him to have exclusive control of his relationships. So free association cannot be a subjective right. Perhaps we should consider it an objective right. But it is hardly perspicuous to categorise this fundamental human right alongside a licensee's conditional and contingent entitlements to operate dance halls. And it would be plain wrong to go on to speak of it as a privilege. ${ }^{77}$ Analogously, Guibault's argument that user's entitlements are not subjective rights does not warrant any suggestion they are mere privileges created by the reflex effect of law. At best her argument establishes a point of distinction between different rights - not an evaluation of primacy.

But let us return to Guibault's swift dismissal of user's rights as subjective rights. Consider how we delineate any right's object. When we come at user's rights from the perspective of intellectual property it is easy enough to think the object of the right is the idea or expression the user asserts copying or access rights over. If this construal of the right is correct, then, as observed above, user's rights are not subjective rights. But this way of characterising the right's object is not our only option. Consider the right to bodily mobility: this is, surely, a subjective right. When we exercise our bodily rights in choosing to walk to a local park, we have an intimate relationship with our body, we have powerful control over it, and others are under stringent duties not to violate that relationship. But why is our body considered the object of the right? Why not the action of walking? Why not our destination - the park? If these were the object of the

\footnotetext{
${ }^{72}$ Guibault, Copyright Limitations and Contracts, 2002, pp.104-106.

${ }^{73}$ Guibault, Copyright Limitations and Contracts, 2002, pp.92-93. The terms "subjective" and "objective" rights are notoriously slippery. For our purposes I simply accept Guibault's characterisation and proceed from that basis.

${ }_{75}^{74}$ Guibault, Copyright Limitations and Contracts, 2002, p.93.

${ }^{75}$ Guibault, Copyright Limitations and Contracts, 2002, pp.95-96.

${ }^{76}$ Guibault, Copyright Limitations and Contracts, 2002, p.91.

${ }^{77}$ At minimum, free association is a liberty-immunity conjunct. Guibault suggests there is a relationship of resemblance between subjective rights and Hohfeld's claim-right, and a relationship of practical equivalence between objective rights and Hohfeld's privilege/liberty (Guibault, Copyright Limitations and Contracts, 2002, pp.94, 98). These are both mistakes. Claim-rights do not resemble subjective rights because holding a claim-right does not grant its owner any control-rights whatsoever-for that we necessarily need liberties and powers. Liberties are not practically equivalent to objective rights because there are liberties constituting essential incidents of subjective rights (e.g. property rights) and there are objective rights (e.g. Guibault's dance hall operator's entitlements) containing at least some immunities. There are probably even objective rights containing no liberty-element whatsoever: e.g. to be legally entitled for the state to pay you $\$ 100$.
} 
right, then we do not have the required control and intimacy. This concern may seem pretty oblique - until we realise how fundamentally it matters in the context of user's rights. Consider the right to learn for oneself - understood as the capacity to use our body, senses and mind in order to apprehend, understand, remember and utilise knowledge about our world. Here, as with bodily mobility, the plausible construal of the object of the right is our learner's body and mind, over which she has absolute intimacy and potent control. Plausibly therefore, it is a subjective right sensu Guibault. Now consider: when her right to learn ranges over others' ideas and writings, does the object of her right change? Is it now to be considered those ideas and writings, instead of her body and mind? I submit that accepting this characterisation is as unworkable as saying the right to bodily mobility changes its object (and hence its status as a subjective right) every time the right holder changes her direction or mode of ambulation. But if the object of the right to personal learning remains the right holder's body and mind then there is no impediment to characterising it as a subjective right. This does not automatically mean the subjective right to personal learning cannot stop at the boundaries of intellectual property, of course, any more than the subjective right to bodily movement cannot stop at the boundaries of private property. It just means we are balancing rights against rights. We are working out if in this instance the author's relationship of intimacy and control over his created idea warrants limiting the learner's relationship of intimacy and control over her searching body and inquiring mind — and vice versa.

\section{Conclusion}

In summation, I have examined and repelled a number of critiques made against the idea of user's rights. Samuels criticised the lack of systematic theory behind public domain commentary; he doubted the capacity of any one moral concern to explain the public domain's makeup, and he worried rights language would require all-or-nothing answers to complex questions. I rebutted these critiques by outlining a specific group of user's rights, and observing that such rights - like other rights such as free speech — cannot be expected to explain every intricacy of the law. Similarly analogising to free speech, I rejected Samuels' assertion that rights discourse necessarily leads to all-or-nothing solutions. Next, Cahir raised queries relating to the nature and structure of user's rights. Against his concerns, I argued user's rights may include Hohfeldian claims of various types, but also that we should - on the basis of both best theory and practice - reject Cahir's lynchpin contention that rights are exclusively claims. I argued further there was no impediment to rights-based theories imposing justiciable duties on specific individuals in order to secure others' access rights, and that the informational policy subsisting in the law of private property was more user-friendly than Cahir envisaged. Finally, in response to Guibault's analysis, I argued the objective/subjective distinction should be understood as discerning a point of difference rather than one of primacy, but that in any case the most plausible construal of the object of user's rights - the user's investigating body and inquiring mind - allowed such rights to be categorised as subjective.

In all, I have aimed to vindicate the general use of rights language in application to user's entitlements to ideas and information. Of course, this hardly shows talk of "user's rights" is justified in every instance it is used. Such evaluations must be made on a case-by-case basis. However, in those cases where the law can be shown to grant claims, powers or liberty-immunity conjuncts to an individual, grounded in the importance to that individual of their having access to some particular idea, or access to a rich tapestry of ideas, or having the capacity to search ideas out for themselves, or to speak out about what they have learned, the weight of the foregoing arguments ensure there is no impediment to the substantive assertion that this individual has user's rights. 